\title{
MALAYSIA'S MEMBERSHIP AT THE UNITED NATIONS SECURITY COUNCIL 2015-2016: SUCCESSES AND SETBACKS
}

\author{
Murni Abdul Hamid ${ }^{a}$
}

\begin{abstract}
This article analyses Malaysia's membership as a non-permanent member of the United Nations (UN) Security Council in 2015 and 2016, focusing on major successes achieved and challenges faced throughout the two-year term. Among Malaysia's key achievements in the UN were on the protection of children in armed conflict and on the question of Palestine, especially relating to illegal Israeli settlements. Malaysia also played an important role in pushing for openness and inclusivity in the selection process of the new UN Secretary-General. However, Malaysia's attempt to pursue accountability for the downing of Malaysia Airlines Flight MH17 in eastern Ukraine was derailed by a veto from a permanent member of the Council. The highly contentious issue of Security Council reform also remains stagnant, despite Malaysia's long-standing efforts to push for comprehensive reform.
\end{abstract}

Keywords: United Nations Security Council, UN Secretary-General, Palestine, Children in Armed Conflict, MH17, Security Council reform

\section{INTRODUCTION}

On 1 January 2015, Malaysia began its membership at the United Nations Security Council (UNSC) for the fourth time in the country's history. Malaysia successfully secured 187 out of 192 votes from UN member states - well above the minimum requirement of 128 votes for a seat as a non-permanent member of the UNSC. Thus, for two years in 2015 and 2016, Malaysia joined the most powerful decision-making body of the UN, with a mandate under the UN Charter to maintain international peace and security. Prior to this, Malaysia had served on the Council in 1965, in 1989-1990 and later, in 1999-2000. Alongside Malaysia, New Zealand, Angola, Spain, and Venezuela were also elected to the non-permanent seats of the Council for 2015-2016, while Turkey lost a tight race to Spain.

Malaysia's subsequent actions and policy choices as a UNSC member reflected its structural realities and constraints as a small country in the international system with limited political, economic, and military clout on the global stage, as illustrated by neoclassical realism theory (Rose, 1998). Compared to the superpowers in the permanent seats of the Council, Malaysia's "relative material power capabilities" in the international system necessitate close cooperation with other middle powers and like-minded countries

a Murni Abdul Hamid (murni@kln.gov.my) is a Deputy Chief of Mission, Embassy of Malaysia in Washington D.C. United States of America. 
in the Council in pushing its agenda forward (Rose, 1998). Meanwhile, domestic considerations played an important role in determining priority areas for Malaysia, particularly in pushing for the Palestinian cause and in promoting its domestic agenda of moderation, based on the country's UNSC membership theme "Peace and Security through Moderation". Thus, in discussing various issues at the UNSC, Malaysia pushed for the values of moderation, tolerance, and inclusivity to counter violent extremism and achieve peace, security, and development.

Throughout its two-year stint at the UNSC, Malaysia had achieved some milestones at the UN, but also faced several setbacks in pursuing its national agenda relating to the maintenance of international peace and security. Within that period, Malaysia became President of the Security Council twice, i.e. in June 2015 and August 2016. As Council President, a Council member would have more leeway in determining the direction and agenda of the Council for the month, and Malaysia took the opportunity to push its agenda on the protection of children in armed conflict.

\section{MAIN ACHIEVEMENTS}

\section{Protection of Children in Armed Conflict}

Throughout 2015 and 2016, Malaysia held the Chairmanship of the UNSC Working Group on Children and Armed Conflict (CAAC). As the Chair of the CAAC Working Group, Malaysia's role was to oversee and coordinate the official work of the body, including organising and chairing formal and informal meetings, convening discussions on UN reports relating to grave violations against children, as well as drafting and leading negotiations on recommendations to improve the protection of children in armed conflict for specific countries.

Being defenceless and voiceless, children normally bear the brunt of violent conflicts. As the Chair of the Working Group on CAAC, Malaysia played a key role in highlighting the issues of child protection in the wider work of the Security Council, for example, when the Council was discussing the issues of Palestine, Yemen, Syria, Nigeria, Sudan/South Sudan, the Central African Republic, or counterterrorism. Among others, Malaysia sought to ensure specific focus on the protection of children when discussing these country-specific issues or when considering an outcome document by the Council, such as a resolution or statement. Malaysia also pushed for the protection of children in various UN peacekeeping mandates to ensure that the mandates would take into account the needs and concerns of children affected by armed conflict.

On 9 June 2015, Malaysia collaborated with Conflict Dynamics International, an international NGO, to organise a side event at the UN to launch the Children and Armed Conflict Accountability Framework. The Framework, developed by Conflict Dynamics International through the contributions of more than 200 stakeholders and field-based country case studies, is aimed at providing practical resources to promote accountability for violations and abuses committed against children in armed conflict. 
The highlight of Malaysia's achievement on this issue was the successful adoption of Security Council Resolution 2225 on the protection of children in armed conflict in June 2015 (UN Security Council, 2015). Initiated by Malaysia during its Presidency of the Security Council, the resolution received unanimous support from Council members when it was tabled during a high-level Security Council Open Debate on 18 June 2015, chaired by then Malaysian Foreign Minister YB Dato' Sri Anifah Aman (UN Security Council, 2015). Among those who participated in the Open Debate were UN SecretaryGeneral Ban Ki-moon and over 70 UN member states. The fact that Resolution 2225 was co-sponsored by $53 \mathrm{UN}$ member states further reflected the international community's strong support and commitment to protect the rights of children in armed conflict, as led by Malaysia.

The focus of Resolution 2225 was on the abduction of children by armed groups and non-state actors, such as ISIL or Boko Haram, in view of alarming trends of mass abductions of children as part of their systematic campaigns of violence against the civilian population. The abductions further led to other serious violations of international humanitarian law such as forced recruitment of children as child soldiers, rape and other forms of sexual violence, slavery, forced labour, hostage-taking, and use as human shields. The shocking abduction of 276 schoolgirls in Chibok, Nigeria in 2014 by Boko Haram was one such instance. Meanwhile, in Syria and Iraq, ISIL has abducted over 1,000 children, particularly from minority communities.

In practical terms, the resolution added abduction as a new criterion or trigger so that perpetrators of abduction would be listed in the Secretary-General's annual report. The purpose of the listing is to hold them accountable for violations of international humanitarian law. Once listed, the perpetrators would be subjected to close monitoring and scrutiny by the UN and periodical reporting to the Security Council, who would then consider ways to address and alleviate such violations against children. The UN would also engage with the relevant parties who are listed in the Secretary-General's report and come up with an Action Plan to alleviate violations against children.

Prior to Resolution 2225, there were four triggers for listing in the SecretaryGeneral's annual CAAC report, i.e., the killing and maiming of children; rape and other forms of sexual violence; recruitment and use of children; and attacks on schools and hospitals. Abduction of children was not in the list. Thus, with the adoption of Resolution 2225 introduced by Malaysia, it constitutes a milestone in the protection of children in armed conflict by broadening the scope of wrongdoings committed against children that would call for close scrutiny and accountability by the UN.

\section{Palestine}

Malaysia's most notable accomplishment during its two-year term at the UNSC was on the issue of Palestine. For many years, the international community in general and the UNSC in particular have been suffering from "Palestine fatigue". The last UNSC Resolution reaffirming the two-state solution was way back in 2003 although the realities on the ground have slowly but surely eroded the possibility of a viable Palestinian state, 
largely due to the expansion of illegal Israeli settlements in the occupied West Bank. For over three decades, not a single UNSC resolution on illegal Israeli settlements managed to be adopted by the Council due to US veto. Indeed, the US had exercised its veto on draft UNSC resolutions on Israel-Palestine more than 40 times since 1970.

Driven largely by its strong domestic support on the issue of Palestine, Malaysia took the opportunity as a UNSC member to revive international attention on Palestine. In particular, Malaysia, working with like-minded Council members, championed the Palestinian cause through unprecedented use of the "Arria-formula meetings" of the UNSC, i.e. informal and normally confidential meetings, with procedural flexibilities compared to official meetings of the Security Council. This allows Council members more leeway in discussing contentious and divisive topics in the Council. Furthermore, Arria-meetings, unlike official Council meetings, allow the participation of non-UN briefers, such as academicians, legal experts or NGOs. This provides the opportunity for Council members to obtain first-hand information and engage in frank discussions with independent experts on the ground relating to the issues at hand.

Throughout its UNSC membership in 2015-16, Malaysia organised three Arriaformula meetings, focusing on the situation in Gaza, on the protection of Palestinian civilians, and on illegal Israeli settlements respectively. It was the first time for the Council to discuss these specific topics in an Arria-formula setting. The only other Arriaformula meeting of the Council on Palestine was held way back in 1997 on the issue of Jerusalem. The first Arria-formula meeting on Gaza that Malaysia held on 20 July 2015, together with Jordan, was aimed at reflecting on the situation on the ground one year after the 2014 Israeli military offensive against Gaza, as well as highlighting Gaza's reconstruction needs, the crippling effects of the illegal Israeli blockade, and the dire humanitarian situation on the ground. On 6 May 2016, Malaysia, together with Egypt, Angola, Senegal, and Venezuela, held another Arria-formula meeting on the protection of Palestinian civilians, whereby the Council received briefings from a legal scholar and human rights advocates on the grave violations of human rights suffered daily by the Palestinian civilian population living under repressive military occupation.

In their presentations, the speakers reminded Council members and UN member states of their legal, political and moral obligations to protect Palestinian civilians in accordance with international law, including the Fourth Geneva Convention and 1907 Hague Regulations, various UN resolutions, the UN Charter, and international standards of human rights. The speakers further outlined possible measures that the international community could consider to ensure that Israel abide by its legal obligations under international humanitarian and human rights law, such as the enactment of penal legislation at the domestic level to search for and prosecute or extradite persons committing or ordering the commission of grave breaches of the Convention, the imposition of diplomatic or economic sanctions, including restrictions on foreign trade, investment and aid, the appointment of a protecting power mandated by the UN Security Council, the imposition of sanctions under the Charter or resort to the International Criminal Court and the International Court of Justice. These measures can be temporary, 
pending an end to Israeli military occupation and the realisation of Palestine's legitimate right to self-determination.

The final Arria-formula meeting of the Security Council held by Malaysia on 14 October 2016 on the issue of illegal Israeli settlements was by far the most significant in terms of impacts and implications. As the lead organiser of the meeting, Malaysia collaborated again with Egypt, Angola, Senegal, and Venezuela, to prepare the ground towards decisive Council action to halt Israeli settlement expansion. The meeting came at a crucial time in view of aggressive settlement expansion by Israel in recent years, which led to increasing settler violence, home demolitions, land confiscations, discriminatory policies, as well as the denial of development, infrastructure, and natural resources. Furthermore, for the first time ever, the Israeli Parliament was considering to retrospectively legalise outposts, which are Israeli settlements built in the occupied West Bank without the authorisation from the Israeli authorities.

In their presentations at the Arria-meeting on settlements, representatives from civil society and the academic world, including an Israeli human rights organisation (B'Tselem) and a US-based NGO (Americans for Peace Now), provided compelling arguments and poignant testimonies to push the Council towards action on the issue of illegal Israeli settlements (UN Security Council, 2016). Among others, the speakers argued that the Israeli government's policies relating to settlements were undermining the very existence of Israel as a democracy and as a country based on Jewish values. They also viewed the ongoing military occupation of Palestine by Israel as a threat to Israel's security and to its very existence.

As the lead organiser of the informal Council meeting on settlements, Malaysia highlighted the urgent need for the Security Council to use the various tools at its disposal and to take urgent action to halt Israeli settlement activities, which are illegal under international law and threatens the prospect of a two-state solution. Malaysia also raised the obligations imposed under international law on the occupying powers, especially the Fourth Geneva Convention, to protect the general welfare of the inhabitants of an occupied territory, including protection for their property and protection from forcible transfer (Ibrahim, 2016). In a major departure from the normal procedures for Arriameetings, Malaysia succeeded in having the meeting on settlements broadcast live and permanently archived on the UN website, despite strong resistance from certain quarters. This helped to further amplify the message sent by the speakers on the issue of settlements across the globe.

All three Arria-formula meetings on Palestine organised by Malaysia were very well received and saw a huge turnout, with over 100 participants from UN member states and NGOs. They contributed in re-focusing the Council's attention back to the IsraeliPalestinian crisis, instead of being neglected and overshadowed by other conflicts in the region such as on Syria, Yemen, and Iraq. More importantly, the emerging consensus among Council members during the Arria-meetings on settlements and the international attention it garnered laid the ground for follow-up actions at the Security Council. In the weeks following the Arria-meetings on settlements, the Arab League Foreign Ministers 
mandated Egypt, as the sole representative of the Arab Group in the Security Council, to engage in consultations with Council members with a view of tabling a draft resolution on the issue of settlements. Malaysia was strongly supportive of the effort and subsequently co-sponsored the draft resolution, together with New Zealand, Senegal and Venezuela.

However, at the very last minute, Egypt withdrew its draft resolution, apparently due to intense pressure from Israel and then President-elect Trump. Recognising the need to act urgently so as not to lose the window of opportunity for Council action, Malaysia took over the lead to table the draft resolution to halt Israeli settlements, and obtained support from like-minded non-permanent UNSC members, i.e., New Zealand, Senegal, and Venezuela. Thus, the four countries representing the Asia-Pacific group, the Western group, the African Group, and the Latin American group in the Security Council came together to send a strong signal on the universal support for the initiative. Malaysia's collective effort also received clear support from other Arab countries in the region. At that point, Malaysia sincerely believed that postponing the tabling of the draft resolution would eventually kill the text, especially with the uncertainties surrounding the policies of the new US administration.

In the end, the collective effort to push for the draft resolution proved to be successful as it was adopted by the Council as Resolution 2334 on 23 December 2016, with a strong show of support among Council members of 14 votes in favour and 1 abstention by the US (UN Security Council, 2016). Loud applause erupted in the august Council Chamber when the resolution was adopted, reflecting the widespread relief, exhilaration and even astonishment among Council members and the audience that the resolution was not vetoed by the US, as had occurred over 40 times in the past decades.

The adoption of Security Council Resolution 2334 was indeed historic and provided a victory to the two-state solution. Resolution 2334 was the first successful Security Council resolution on settlements in over 36 years and it is legally binding on all UN member states. The last attempt to push for a draft resolution in the Council on settlements failed in 2011, as it was vetoed by the US, although all other 14 Council members supported it. Security Council Resolution 2334 calls upon Israel to immediately and completely cease all settlement activities in Occupied Palestinian Territory, including East Jerusalem. It further reaffirms that the establishment of settlements by Israel in Occupied Palestinian Territory since 1967 has no legal validity and constitutes a flagrant violation under international law. The resolution also requested UN member states to distinguish between Israeli territory and territories occupied since 1967 and urged member states not to recognise any changes to the 4 June 1967 lines, including with regard to Jerusalem, other than those agreed by the parties through negotiations.

While the focus of Resolution 2334 was on illegal Israeli settlements, it is but a symptom of the long-standing military occupation of Palestinian territory by Israel since 1967. Thus, Resolution 2334 is also significant in the sense that it calls for an end to Israeli occupation. It also outlines measures to be taken by both the conflicting parties (i.e. Palestine and Israel), as well as actions to be taken by UN member states. In another 
milestone, it created a regular reporting mechanism by UN Secretary-General to the Security Council on the implementation of the resolution every three months. This would ensure renewed, more focused attention, and a more structured approach by the Council in handling the question of Palestine, especially on illegal settlements.

Malaysia believes that Resolution 2334 would serve as an important basis for further action in the event of non-compliance by Israel. Although the resolution does not contain punitive measures in case of non-compliance, it provides a reference point on the issues of settlements, the occupation and the 1967 borders, from which subsequent actions by both sides of the conflict could be measured and judged against. This would thus make it easier for the international community, either bilaterally or multilaterally, to take appropriate action to address possible non-compliance by the parties. Apart from the Arria-formula meetings on Palestine and Resolution 2334, Malaysia also tried to change the prevailing narratives on the Israeli-Palestinian conflict at the Security Council.

First, Malaysia questioned the continuing insistence by the international community, including the Middle East Quartet and most Council members, that direct bilateral negotiation is the only way for the parties to resolve the long-standing conflict. After over two decades since the Oslo Accords and continuing failures to resolve the Israeli-Palestinian conflict through direct bilateral negotiations, Malaysia believes that the time has come to acknowledge that the current approach is fundamentally flawed. Direct bilateral negotiations could only work if the parties are of equal or similar status, if there is political will by the leadership on both sides for peace, and if there is an impartial and honest broker to facilitate the negotiations and pressure both sides to make difficult compromises based on the two-state solution. Unfortunately, in the case of Israel and Palestine, these factors have been absent in the peace process.

Instead, there is an Occupying Power with great military and economic superiority on one side, and an occupied, defenceless people on the other side of the conflict. There is no balance or equality between the two parties, as the occupied Palestinian continue to live under a repressive military occupation and brutal blockade for half a century, face discriminatory treatment and violations of their basic human rights on a daily basis, are dispossessed of their homes and lands, are deprived of natural resources and economic development, and encounter serious restrictions in their movement. Thus, in its statements and interventions as a Security Council member, Malaysia persistently pointed out that insisting on direct bilateral negotiations between such unequal entities would create an unfair advantage to the Occupying Power. The fact that the supposedly "honest broker" in the peace process has been far from impartial and acted more as an extension of the Occupying Power, further erodes the credibility of the whole process.

Yet, the international community in general, and the Security Council in particular, continue to insist that direct bilateral negotiation is the only acceptable means to resolve the conflict. Clearly, a different standard is being applied to Palestine than the one applied to Israel. After all, the State of Israel came into being not through direct bilateral negotiations with countries in the region, but through a UN General Assembly Resolution (UN General Assembly, 1947). However, a similar path is consistently denied 
to the Palestinian people. One unfortunate consequence of insisting on direct bilateral negotiations as the only acceptable path to resolve the Israeli-Palestinian conflict is the rejection of all other efforts by Palestine to seek its legitimate right to self-determination, even peaceful and legal ones through multilateral or legal platforms. The international community, especially the West, has been quick to label such efforts by Palestine as "unilateral actions" and lump them together with Israel's illegal unilateral actions of settlement expansion.

In Malaysia's interventions as a Council member, we urged the international community to differentiate between "unilateral actions" that are peaceful and consistent with international law, aimed at realising the two-state solution, and "unilateral actions" that are illegal, against international law, international standards of human rights and UNSC resolutions, and which undermine the two-state solution. Clearly, the latter should be supported, while the former should be sanctioned. Instead, Palestine had been threatened with punitive measures for trying to hold Israel accountable for alleged war crimes and crimes against humanity at the International Criminal Court (ICC), or for trying to push for its legitimate right of self-determination at the UN or other multilateral platforms.

Malaysia further believes that direct bilateral negotiations would only work if the parties willingly engage in such negotiations in good faith to resolve the conflict. However, in past years, Israel had shown little desire to return to negotiations, continued to increase its land grabs and settlement activities on Palestinian lands, and had actively undermined the two-state solution to prevent the emergence of an independent and contiguous State of Palestine. In such a situation, insisting on direct bilateral negotiations would only serve Israel's interests as the Occupying Power and perpetuate the Occupation while providing a convenient cover for Israel to change the realities on the ground by expanding illegal settlements. Thus, the international community must move away from this flawed approach on the Israeli-Palestinian conflict and allow other peaceful, legal or multilateral avenues for Palestine to advance its legitimate right to selfdetermination, just as Israel did in 1948.

Secondly, another common approach of the international community on the Israeli-Palestinian crisis is to focus on providing incentives to the parties to resolve the conflict and ignoring the need for sanctions even for persistent gross violations of international law, international standards of human rights, and UN resolutions. This was also the position taken by France when it came up with its Middle East Peace Initiative on the Israeli-Palestinian conflict in 2016-2017. While Malaysia supported the French initiative in reinforcing international support for the two-state solution, Malaysia believed that the problem in influencing the parties' behaviour is not due to the lack of incentives, but the lack of sanctions. As Malaysia conveyed in its national statement during the Arria-formula meeting on illegal settlement on 14 October 2016:

It is not that we need more carrots, but we need more sticks to ensure adherence to international law and international human rights standards, as well as to uphold peace and the two-state solution. We have seen how 
providing incentives, whether in the form of the comprehensive Arab Peace Initiative, or billions of dollars in military aid to safeguard its security, did nothing to persuade Israel to move in the right direction for peace. It has not led to Israel granting any concession to uphold the twostate solution. Instead, it has further emboldened Israel into intensifying its settlement activities and entrenching its repressive occupation.

In fact, Malaysia believes that the ultimate incentive for Israel has been offered by the Arab countries over 14 years ago, in the form of the Arab Peace Initiative. The Initiative has also been endorsed by the Middle East Quartet and supported by the UN Secretary-General. Yet, it has been rejected by Israel.

Last year, Israel has received an unprecedented military assistance (from the US), totaling US\$38 billion, covering the period of 10 years.... And yet, merely weeks after the signing of the largest ever military-assistance deal, Israel brazenly announced that it would build even more new settlement housing units. Clearly, there is a need to stop rewarding illegal behaviors that threaten peace and security in the region and beyond. It simply does not work. (Ibrahim, 2016)

Malaysia also compared the situation in the Occupied Palestinian Territory to the apartheid policies in South Africa - which ended after years of political, economic and diplomatic sanctions by the international community for its discriminatory policies and gross violations of human rights. In many ways, the policies of the Israeli regime are worse than the South African apartheid regime due to the existence of a repressive military occupation, the illegal blockade of Gaza, restrictions on movement, diversion of natural resources, indiscriminate killings and excessive use of force against Palestinian civilians, and administrative detentions. As Malaysia had pointed out in various interventions as a Council member, the Security Council has various tools at its disposal, which it had not shied away from using against other countries for much lesser offenses. Malaysia thus insisted that the Israeli-Palestinian conflict should be no exception.

Thirdly, Malaysia has been highlighting the need to address the root causes of the Israeli-Palestinian conflict, rather than focusing on its symptoms. In particular, Malaysia sought to expose the Israeli narrative of using terrorism as a convenient cover to justify the regime's continuing illegal occupation and repressive policies in the Occupied Palestinian Territory. Such a narrative has diverted attention away from the root cause of the conflict, i.e., the prolonged occupation, and served to perpetuate the military occupation, allegedly in response to terrorism, while tragically resulting in an endless cycle of violence. Thus, the Security Council should not only condemn sporadic attacks and acts of violence by Palestinians, but also address the bigger question of what created, fueled and bred such anger, frustration, and despair in the first place, which gave rise to desperate and violent responses. The fact that the international community condemns violent acts of resistance by Palestinians against the Occupation, while at the same time, persistently denying Palestine from various peaceful, legal, and multilateral means to 
achieve its legitimate right to self-determination by insisting on direct bilateral negotiations, makes the approach even more unjust and unacceptable.

Over the decades, it has become clear that the prolonged occupation of Palestine by way of oppression, injustice and discrimination has failed to safeguard Israel's longterm security concerns. Instead, it has brought about despair, anger and extremism, with repercussions that continue to resonate far across the globe. As the former UN SecretaryGeneral Ban Ki-moon stated in his address to the Security Council:

Palestinian frustration is growing under the weight of a half century of occupation and the paralysis of the peace process... as oppressed peoples have demonstrated throughout the ages, it is human nature to react to occupation, which often serves as a potent incubator of hate and extremism (Ban, 2016).

The illegal military occupation of Palestine by Israel reaches its $50^{\text {th }}$ year in 2017 . Yet, the resolution of the conflict is nowhere in sight. The peace process is practically non-existent since its breakdown in 2014 when Israel ended the peace talks unilaterally. The much-anticipated report published by the Middle East Quartet (consisting of the US, Russia, the European Union and the UN) in July 2016, identifying major threats to achieving a negotiated peace, and recommending ways to advance the two-state solution, remains unimplemented (European Union External Action, 2016).

Under the Trump administration, the U.S. has reversed its long-standing position on Israeli settlements by determining that they do not violate international law, contrary to the position of the international community and the International Court of Justice. Since 2017, the Trump administration has recognised Jerusalem as the capital of Israel; relocated the US Embassy from Tel Aviv to Jerusalem; cut US aid to the UN agency for Palestinian refugees; and closed the Palestinian mission in Washington D.C. Incrementally but surely, the Trump administration is moving towards a one-state solution, further extinguishing any hope for a viable Palestinian state.

At the background of this difficult environment and the absence of leadership from the major powers and the Security Council, the role of the international community and regional/multilateral organisations, including the UN, the OIC, and the EU would be more crucial than ever to uphold the two-state solution and ensure adherence to international law, international standards of human rights, as well as the values and principles of the UN Charter by the parties to the conflict.

Malaysia will continue to urge the Security Council to shoulder its legal, political and moral responsibility to end the repressive Israeli occupation. In the interest of maintaining international peace and stability, the Council should use its various tools to sanction settlement activities, the apartheid policy and gross violations of human rights, as well as to ensure accountability, and to support the fundamental right to selfdetermination. Towards this end, UNSC Resolution 2334, as put forward by Malaysia, 
would continue to serve as an authoritative benchmark to put the conflicting parties to task in order to achieve peace in the region based on the two-state solution.

\section{Selection of the New UN Secretary-General}

An interesting experience for Malaysia as a UNSC member was its involvement in the selection process of the new UN Secretary-General to replace Ban Ki-moon, whose term ended by 31 December 2016. According to the UN Charter, "the Secretary-General shall be appointed by the General Assembly upon the recommendation of the Security Council" (UN Charter, 1945). No further requirements were laid down under the UN Charter, whether regarding the term limit, selection process, or regional rotation. In the past 70 years, the selection and voting process for the Secretary-General at the Security Council has been shrouded in secrecy, with dominant roles being played by the permanent members, and minimal roles for the elected members. This is especially true from 1946 to 1971, when the candidature for the first three Secretaries-General of the UN were proposed by the permanent members of the Security Council (Security Council Report, 2016, p.6).

As an elected member of the Council with one vote to choose the new SecretaryGeneral, Malaysia prioritised the selection of the most qualified candidate based on merit, with due consideration to be given to the question of regional rotation. Malaysia was also intent on maximising the role of the ten elected members in the selection of the top UN leadership, so as not to be sidelined by the permanent members in the process. With this in mind, Malaysia convened an informal meeting of the ten elected members of the Security Council in early 2016 to exchange views and explore common positions on the selection process of the Secretary-General (Security Council Report, 2016, p.5). While views among the elected members differed on the issues of gender, geographical rotation, term limit for the new Secretary-General, and the number of candidates to be recommended by the Council to the General Assembly, the elected members were united in their call for an inclusive, transparent and efficient selection process in the Council.

One way of maximising the role of the elected members in the selection process of the Secretary-General was to avoid, or more realistically, to delay, as much as possible, the use of colour-coded ballots in the Council, to ensure that all Council members would have an equal say in the decision, irrespective of their status as permanent or elected members. Historically, colour-coded ballots had been used by Council members over the past two decades to differentiate between the secret votes cast by permanent members (who hold a veto in the selection process) and elected members in selecting the Secretary-General (Security Council Report, 2017, p.7). The use of colourcoded ballots early in the selection process would undoubtedly diminish the role of the elected members and ensure domination of the permanent members in the early phase of the selection process.

In this regard, the unified efforts by the elected members of the Security Council to maximise their role in the selection process by delaying as much as possible the use of coloured straw polls, could be considered as successful. After five rounds of 
undifferentiated straw polls since 21 July 2016, only one colour-coded ballot was held towards the end of the selection process on 5 October 2016. Despite the positive changes in the transparency and openness in the selection process of the Secretary-General, not much has changed in the selection process at the Security Council, which was still shrouded in secrecy. The Council held meetings with each candidate and organised straw polls in private to gauge the support from Council members for each candidate. Calls by the majority of the elected members for a more open and transparent process in the selection process in the Security Council, including in making the result of the straw polls public, were met with strong resistance by some permanent Council members.

Meanwhile, at the UN General Assembly, the latest selection process of the new Secretary-General created historic milestones in terms of openness, transparency, and inclusivity. For the first time since 1950, the General Assembly played a significant and active role in selecting the top UN leadership, instead of merely rubber-stamping the Council's recommendation (Security Council Report, 2016). A combination of factors had led to such changes, including a strong civil society campaign, the strong leadership of the President of the General Assembly, key roles played by UN member states especially those on behalf of the Accountability, Coherence and Transparency (ACT) Group, and the Ad Hoc Working Group on the Revitalisation of the Work of the General Assembly, as well as the inevitable advent of social media which added further pressure for a transparent process (Security Council Report, 2017).

For the first time ever, the candidates for the position of the Secretary-General participated in informal dialogue sessions in the General Assembly, based on GA Resolution 69/321 (UN General Assembly, 2015). During the four public sessions of informal dialogue held between April and October 2017, the candidates gave a presentation and tackled questions from UN member states and representatives of civil society. In addition, on 12 July 2016, a Global Town Hall event was held live on AlJazeera TV, organised by the President of the General Assembly, which provided a spotlight on the candidates and the selection process as never before. During the event, UN member states in particular, and the world in general, obtained further insight into the candidates' positions, knowledge, and priorities, as well as their ability to field tough questions. Malaysia participated in the informal dialogue sessions and the Global Town Hall and posed questions to the candidates through the regional grouping of ASEAN to obtain further clarifications on their positions on international issues that are important to Malaysia.

In another milestone, the Office of the President of the General Assembly created a website on the selection process, which featured the list of nominated candidates and their vision statements (Security Council Report, 2016, p.3). This is in stark contrast with the secretive nomination process in the first several decades of selecting the SecretaryGeneral, when there was "no public record of who was being considered for the position, no written information, and names were simply suggested, almost always by permanent members" (Security Council Report, 2017, p.6). 
The more open selection processes this time around resulted in the largest number of candidates ever being fielded by UN member states (13), and the largest number of women candidates (7). The informal dialogue and Global Town Hall sessions were generally regarded as instrumental in setting the tone in the selection process and in sending signals to the Security Council on the desirability and suitability of the candidates. The open and transparent vetting process at the General Assembly made it "more difficult for a weak candidate to be chosen or for a strong candidate to be vetoed" by the Security Council (Security Council Report, 2017, p.11). In this regard, the openness and transparency in the selection process of the Secretary-General at the General Assembly is believed to have positively influenced the decision-making process at the Security Council.

\section{SETBACKS}

\section{Accountability for the downing of Malaysia Airlines Flight MH17}

The shocking downing of Malaysia Airlines Flight MH17 on 17 July 2014 occurred half a year before Malaysia became a UNSC member. The issue was new to the Council at the time and was discussed under the agenda item of Ukraine at the Council and became a Council agenda item in early 2014 at the start of the Ukraine crisis. Naturally, when Malaysia joined the Security Council in January 2015, MH17 became one of the country's key priorities at the Council.

On 29 July 2015, on behalf of the countries participating in the Joint Investigation Team (JIT) on the downing of MH17 consisting of Australia, Belgium, Malaysia, the Netherlands, and Ukraine, Malaysia tabled a draft resolution at the UN Security Council to establish an international criminal tribunal to ensure justice and accountability for the tragic incident. The draft resolution was a follow-up to Security Council resolution 2166, which was unanimously adopted by the Council on 21 July 2014. Resolution 2166 condemned the downing of Flight MH17, called for a full, thorough, and independent international investigation in accordance with international civil aviation guidelines, called on all States and actors to cooperate fully in the international investigation, and demanded that those responsible be held to account and that all States cooperate fully with efforts to establish accountability. The countries participating in the JIT believed that creating a tribunal under Chapter VII of the UN Charter would accord the tribunal with the highest legitimacy and the most effective mechanism under international law since UN member states would be legally obliged to implement the resolution - crucial for an effective prosecution.

By tabling the draft resolution, Malaysia and other countries participating in the JIT hoped that the Security Council would send a strong signal on its commitment to take action against those who threaten international peace and security by endangering civil aviation and targeting civilian aircrafts. As the initiator of the draft resolution, Malaysia engaged closely with all Council members and held several informal negotiation sessions to discuss the draft resolution and the draft statute of the tribunal. The countries participating in the JIT also engaged in extensive outreach efforts, both in New York and 
in capitals, to seek support from Council members and grieving nations ${ }^{1}$ on the initiative. Malaysia sought to address some concerns expressed by other Council members such as on the timing of the draft resolution since the tribunal would be created before the technical and criminal investigations on MH17 were completed, the independence of the tribunal, as well as the cost and time factors in creating a new international judicial institution.

On the issue of timing of the creation of the tribunal, the countries participating in the JIT followed the precedents set by other ad hoc criminal courts and tribunals such as the ICTY and the ICTR, which were established prior to the completion of criminal investigations. Furthermore, Malaysia believed that creating the tribunal before the result of the investigations were completed would ensure that the tribunal would be as depoliticised as possible. Regardless of whom the perpetrators were, the countries participating in the JIT wanted to ensure that they would not escape the arm of justice. The draft Statute of the Tribunal would also ensure the independence of the judges and the Prosecutor as it provided the latter with full power to decide on the strength and relevance of evidence of the JIT investigation and to initiate his or her own investigation as he or she seems fit.

In addressing concerns on the time and cost factors in creating a new international criminal tribunal, the draft Statute of the tribunal was improved based on lessons learnt from existing international criminal tribunals, such the ICTY, the Special Tribunal for Lebanon, the ICTR, and the Special Court for Sierra Leone. These improvements included the composition of the Chambers, the inclusion of trial in absentia, the working language, and the Rules of Procedure and Evidence.

Unfortunately, despite Malaysia's extensive efforts to bridge the gap in the position of Security Council members, the draft resolution failed to be adopted by the Council as it was vetoed by Russia, despite obtaining 11 votes of support from Chad, Chile, France, Jordan, Lithuania, Malaysia, New Zealand, Nigeria, Spain, the United Kingdom, and the United States of America. Three other Council members abstained from voting, i.e., China, Venezuela, and Angola, mainly due to their position that the vote was untimely (UN Security Council, 2015).

In vetoing the draft resolution, Russia questioned the impartiality of the JIT-led investigation and reiterated its call for an UN-led investigation. Russia also rejected the link between the downing of MH17 and threats to international peace and security, as it regarded the incident as a criminal matter that was beyond the mandate of the Security Council (UN Security Council, 2015, p.5). Furthermore, Russia's dim views on international criminal tribunals in general contributed to its opposition to the creation of a new international criminal tribunal on MH17.

Malaysia was deeply disappointed by the failure of the Security Council to adopt the draft resolution to ensure justice for the victims' families and loved ones, and accountability for the perpetrators. Despite the setback, Malaysia remained steadfast in its determination to pursue accountability for the perpetrators and to ensure justice for the 
victims on board MH17. Together with other JIT countries, Malaysia continues to explore other viable options and prosecuting mechanisms to ensure that justice would be served, and the perpetrators held accountable for their actions, whether within or outside the UN system.

\section{Security Council reform}

As a UN member state, Malaysia has long championed comprehensive reforms of the Security Council, especially in the 1990s. Malaysia has been calling for a more transparent decision-making process of the Council, more accountability to the wider UN membership, a more democratic system and a more equitable geographical representation in the Council (Ismail \& al-Attas, 2014). The use of veto power by the five permanent members of the Security Council is particularly contentious since its uses to protect the national interests of the permanent members had often contradicted the need to maintain international peace and security.

However, over the decades, persistent efforts to push for comprehensive Security Council reforms by various member states and groupings had not yielded much progress. Reforming the Security Council by changing its composition and privileges would entail amending the UN Charter, with two-thirds of the votes in the General Assembly, followed by ratification by two-thirds of UN member states, including all permanent members of the UNSC, within an agreed-upon timeframe (Ismail \& al-Attas, 2014). Since the establishment of the UN, the Security Council had only undergone one restructuring - to increase the number of seats in the Council from 11 to 15, in 1963. In recent years, one permanent member of the Council, i.e., France, has been advocating a refrain in the use of the veto in cases involving genocide, war crimes and crimes against humanity. However, the initiative by France still proved difficult to sell to other permanent members especially the US, Russia and China.

Thus, while Malaysia continues to support the call for a comprehensive reform of the Security Council in the interest of international peace and security, Malaysia found it more realistic and prudent to focus its limited resources on issues that could yield tangible results within its short two-year membership in the Council, such as on Palestine and on the protection of children in armed conflict.

\section{CONCLUSION}

Towards the end of Malaysia's membership at the Council, some agenda items of the Council had not made much progress or had even worsened in the past two years, including Syria, Ukraine, South Sudan, Yemen, and Mali. However, as a small country with limited power and resources, there is a limit as to what Malaysia could achieve as an elected Council member, especially when the interests of the permanent members are at stake.

In view of its relative material power capabilities, Malaysia sought to push its agenda on the international scene by cooperating very closely with like-minded countries 
in the UNSC such as Jordan and Egypt on the issue of Palestine, and New Zealand and Spain on MH17 and the protection of children in armed conflict. As much as possible, the ten elected members of the Security Council would try to form a united front to safeguard their interests and promote transparency and inclusiveness in the working methods of the Council, especially in the selection of the new UN Secretary-General. Meanwhile, Malaysia's domestic considerations, particularly regarding support for Palestine and call for accountability for the downing of MH17, set Malaysia's priorities and policy decisions as a UNSC member.

Despite its limitations, Malaysia has admirably succeeded in pushing its key initiatives during the two-year membership at the UN Security Council, particularly on Palestine and the protection of children in armed conflict. Malaysia's contributions on these issues have undoubtedly left a permanent mark at the UN and proved that a small country could punch above its weight in the international arena, in line with its independent and principled foreign policy to safeguard international peace and promote humanity, justice, and equality.

\section{Notes}

1 Countries with citizens on board MH17, consisting of Australia, Belgium, Canada, China, Germany, Indonesia, Ireland, Israel, Italy, Malaysia, New Zealand, Philippines, Romania, South Africa, United Kingdom, United States, and Vietnam.

\section{REFERENCES}

"Appointing the un secretary-general: The challenge for the security council." (2016, June 30), UN Security Council Report. Retrieved from: https://www.securitycouncilreport.org/atf/cf/\%7B65BFCF9B-6D27-4E9C-8CD3CF6E4FF96FF9\%7D/appointing_unsg_2016.pdf

Ban, K. M. "Secretary-general's remarks to the security council on the situation in the Middle East." (2016, January 26), The UN Secretary General. Retrieved from https://www.un.org/sg/en/content/sg/statement/2016-01-26/secretary-generalsremarks-security-council-situation-middle-east

"Chapter XV: The secretariat, article 97." (1945), United Nations (UN) Charter. Retrieved from http://www.un.org/en/charter-united-nations/index.html

"Children and armed conflict, S/RES/2225(2015)" (2015, June 18), UN Security Council Resolution 2225. Retrieved from https://undocs.org/S/RES/2225(2015).

"Future government of Palestine, A/RES/181(II)" (1947, November 29), UN General Assembly Resolution 181(II). Retrieved from https://undocs.org/en/A/RES/181(II)

Ibrahim, R. "Intervention by Malaysia at the un security council arria-formula meeting on illegal Israeli settlements: Obstacles to peace and the two-state solution." (2016, October 14), The UN Security Council. Retrieved from http://webtv.un.org/search/arria-formula-meeting-of-the-security-council-illegal- 
israeli-settlements-obstacles-to-peace-and-the-two-statesolution/5171065464001?term=arria

"In hindsight: Resolution on Israeli settlements." (2017, January 31), UN Security Council Report. Retrieved from https://www.securitycouncilreport.org/monthlyforecast/2017-02/in_hindsight_resolution_on_israeli_settlements.php

Ismail, R. \& al-Attas, S. S. (2014). A un chronicle: 1988-1998. Kuala Lumpur: Institute of Diplomacy and Foreign Relations.

"Record of arria-formula meeting on illegal Israeli settlements: Obstacles to peace and the two-state solution." (2016, October 14), UN Security Council. Retrieved from http://webtv.un.org/search/arria-formula-meeting-of-the-security-council-illegalisraeli-settlements-obstacles-to-peace-and-the-two-statesolution/5171065464001?term=arria

"Record of meeting of the un security council, children and armed conflict, s/pv.7466" (2015, June 18), UN Security Council. Retrieved from https://undocs.org/en/S/PV.7466

"Record of meeting of the un security council, the situation in the middle east, including the Palestinian question, s/pv.7853." (2016, December 23), UN Security Council. Retrieved from https://undocs.org/en/S/PV.7853

"Record of meeting of the un security council, letter dated 28 february 2014 from the permanent representative of Ukraine to the united nations addressed to the president of the security council, s/pv.7498." (2015, July 29), UN Security Council. Retrieved from https://undocs.org/en/S/PV.7498

"Report of the Middle East quarter." (2016, July 1), European Union External Action. Retrieved from https://eeas.europa.eu/generic-warning-systemtaxonomy/404_en/7022/Report\%20of\%20the\%20Middle\%20East\%20Quartet

"Revitalization of the work of the general assembly, A/RES/69/321." (2015, September 22), UN General Assembly Resolution 69/321. Retrieved from https://undocs.org/en/A/RES/69/321

Rose, G. (1998), Neo-classical realism and theories of foreign policy: A Review. World Politics, 51, 1, 144-172.

"The un secretary-general selection and appointment process: Emerging from the shadows." (2017, April 4), UN Security Council Report. Retrieved from https://www.securitycouncilreport.org/atf/cf/\%7B65BFCF9B-6D27-4E9C-8CD3CF6E4FF96FF9\%7D/research_report_appointment_of_the_secretary_general_2017 .pdf

"The situation in the Middle East, including the Palestinian question S/RES/2334(2016)" (2016, December 23), UN Security Council Resolution 2334. Retrieved from https://undocs.org/S/RES/2334(2016) 